\title{
A Case of Squamous Cell Carcinoma Occurred in the External Auditory Canal Misdiagnosed as a Keratoacanthoma after Radiotherapy for Kimura's Disease
}

\author{
Yoon Seok Choi ${ }^{1}$, Si-Youn Song ${ }^{1}$, Yong-Dae Kim ${ }^{1,2}$, and Chang Hoon Bae ${ }^{1}$ \\ ${ }^{I}$ Department of Otorhinolaryngology-Head and Neck Surgery, College of Medicine, Yeungnam University, Daegu; and \\ ${ }^{2}$ Regional Center for Respiratory Diseases, Yeungnam University Medical Center, Daegu, Korea
}

\author{
방사선 치료를 받은 기무라씨병 환자에서 각화극세포종으로 오인된 외이도 편평상피세포암 1 예 \\ 최윤석 ${ }^{1} \cdot$ 송시연 $^{1} \cdot$ 김용대 ${ }^{1,2} \cdot$ 배창훈 $^{1}$ \\ 영남대학교 의과대학 이비인후-두경부외과학교실, ${ }^{1}$ 영남대학교병원 권역 호흡기 전문질환센터 ${ }^{2}$
}

\author{
Received June 7, 2016 \\ Revised August 12,2016 \\ Accepted August 18, 2016 \\ Address for correspondence \\ Chang Hoon Bae, MD, PhD \\ Department of Otorhinolaryngology- \\ Head and Neck Surgery, \\ College of Medicine, \\ Yeungnam University, \\ 170 Hyeonchung-ro, Nam-gu, \\ Daegu 42415, Korea \\ Tel $+82-53-620-3782$ \\ Fax $+82-53-628-7884$ \\ E-mail baich@med.yu.ac.kr
}

\begin{abstract}
Malignancy of the external auditory canal (EAC) is a rare tumor. Among the malignancies of EAC, squamous cell carcinoma (SCC) is the most common pathologic type. The causes of SCC of EAC may be exposure to ultraviolet rays, cholesteatoma, chronic otitis externa, and rarely radiotherapy. SCC of EAC has the diverse and non-specific clinical features including mass of tissue, otorrhea, otalgia, tinnitus, and facial palsy which make it difficult to distinguish between SCC and benign tumor. Recently, we experienced a case of SCC of EAC occurred in the left external auditory canal after radiotherapy for Kimura's disease, which was misdiagnosed as keratoacanthoma at first. The findings of this case suggest that when it is difficult to distinguish SCC from benign tumor of EAC, the excisional biopsy including enough resected margin and base of tumor is needed for an exact diagnosis.
\end{abstract}

Korean J Otorhinolaryngol-Head Neck Surg 2017;60(11):575-8

Key Words Keratoacanthoma $\cdot$ Radiotherapy $\cdot$ Squamous cell carcinoma.

\section{서 론}

외이도 악성종양은 매우 드문 질환으로 병리학적으로는 편 평상피세포암이 가장 많은 비율을 차지한다. ${ }^{1,2)}$ 외이도 편평 상피세포암의 가장 흔한 신체 소견은 외이도 종물이고, 혈행 성 이루, 이통, 이명, 현훈, 두통, 안면마비 등 다양한 임상양 상을 나타내며, 각화극세포종 등과 같은 외이도 양성종양과 육안적 구별이 어려워서 감별하기가 힘든 경우도 많다. ${ }^{2,3)}$

외이도 편평상피세포암의 원인으로는 지속적인 자외선 노

This is an Open Access article distributed under the terms of the Creative Commons Attribution Non-Commercial License (http://creativecommons.org/licenses/by-nc/4.0) which permits unrestricted non-commercial use, distribution, and reproduction in any medium, provided the original work is properly cited.
출, 진주종, 만성 외이도염 등이 보고되고 있으며, 매우 드물 게는 방사선 치료가 외이도 편평상피세포암의 원인으로 보 고되는데 이는 주로 비인강암의 방사선 치료 후 발생하는 경 우이다. ${ }^{4-6)}$

저자들은 기무라씨병(Kimura's disease)으로 2014년 7월부 터 2015년 7월까지 좌측 이하선 부위에 방사선 치료를 받아 온 46세 남자 환자에서 우연히 발견된 좌측 외이도 종물에 대 해 시행한 절개생검에서 각화극세포종으로 진단되어 적출술 을 시행한 후 조직병리학적 검사에서 편평상피세포암으로 진 단된 1 예를 경험하였기에 문헌고찰과 함께 보고하고자 한다. 


\section{증 례}

46세 남자 환자가 두 달 전 우연히 발견한 좌측 외이도 종물 을 주소로 내원하였다. 좌측 외이도의 경한 이물감 외 다른 이과적 증상은 없었다. 신체 검사상 약 $0.7 \times 0.7 \mathrm{~cm}$ 크기로 분화구 모양의 반구형이면서 중앙에 각질이 차 있는 무통성 종물이 좌측 외이도 바깥쪽 하방에 관찰되었다(Fig. 1A). 과 거력상 환자는 타병원에서 2006년도에 기무라씨병으로 진단 받은 후 2013년도와 2014년도에 기무라씨병으로 인해 발생 한 좌측 이하선 부위 종물에 대해 두 차례 절제술을 시행받 았고, 2014년 7월에는 좌측 이하선 부위에 $30 \mathrm{~Gy}, 2015$ 년 7월 에는 좌측 이하선 상방 부위에 $20 \mathrm{~Gy}$ 의 방사선 치료를 시행 받았다. 3 년에 걸친 치료기간 동안 시행한 이학적 검사와 영
상학적 검사를 후향적으로 확인해 본 결과 과거에는 좌측 외 이도에 이상소견은 관찰되지 않았다.

좌측 외이도 종물에 대해 정확한 진단을 위해서 절개생검을 시행하였고, 조직병리학적 검사상 양성종양인 각화극세포종 으로 진단되어(Fig. 2A and B), 국소마취하 좌측 외이도 종물 적출술을 시행하였다. 수술소견상 약 $0.7 \times 0.7 \mathrm{~cm}$ 크기로 분 화구 모양의 반구형이면서 중앙에 각질이 차 있는 종물이 좌 측 외이도 바깥쪽 하방에 있었으며 주위 피하조직 일부와 함 께 제거하였다. 종물은 피하조직과 연골부위의 국소침윤은 관찰되었으나, 주위 골조직과 연부조직의 침윤은 관찰되지 않았다(Fig. 1B). 그러나 수술 후 시행한 조직병리학적 검사상 분화가 좋으면서 기저 부위로 초기 기질침윤을 보이는 편평상 피세포암으로 진단되었다(Fig. 2C and D). 따라서 편평상피세
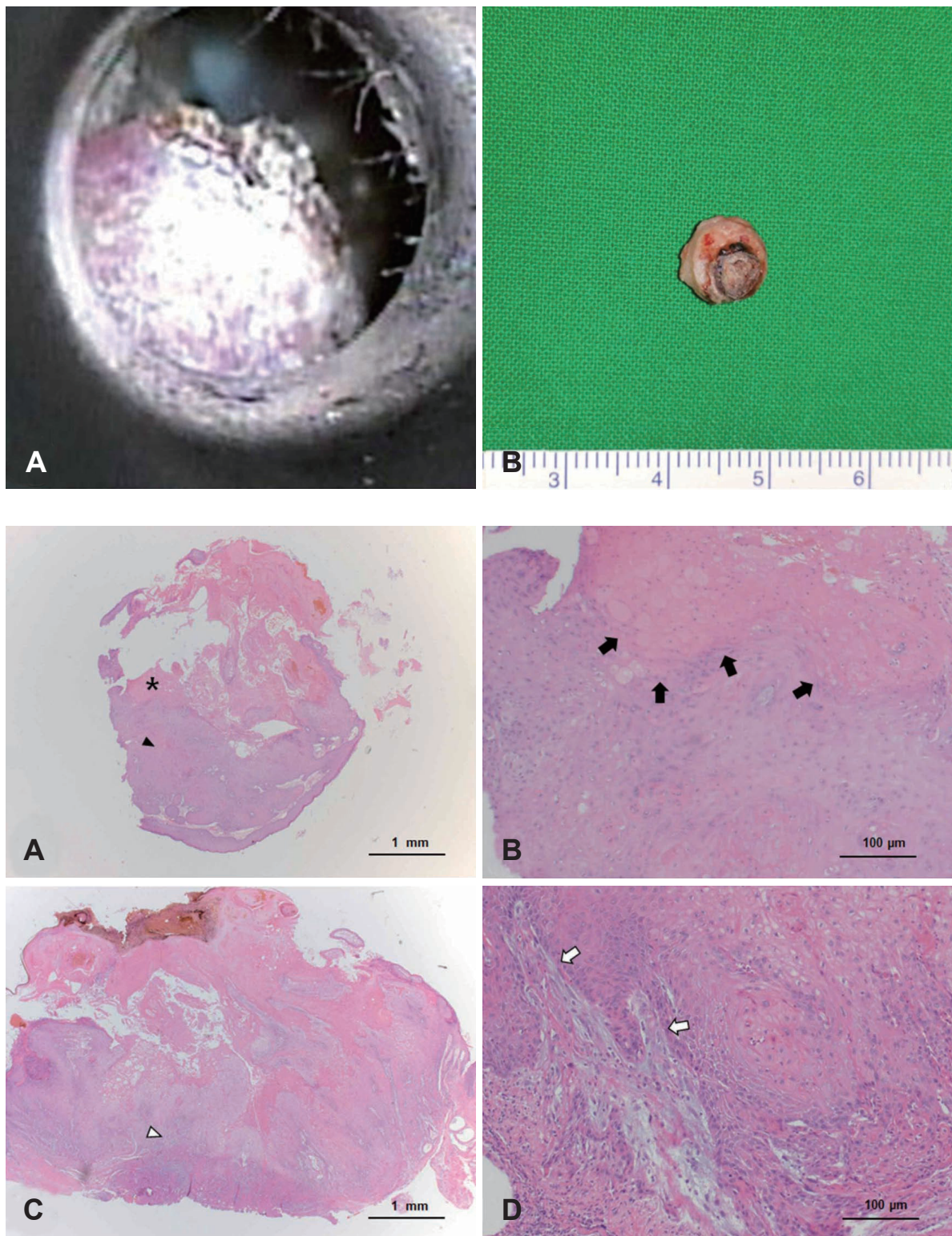
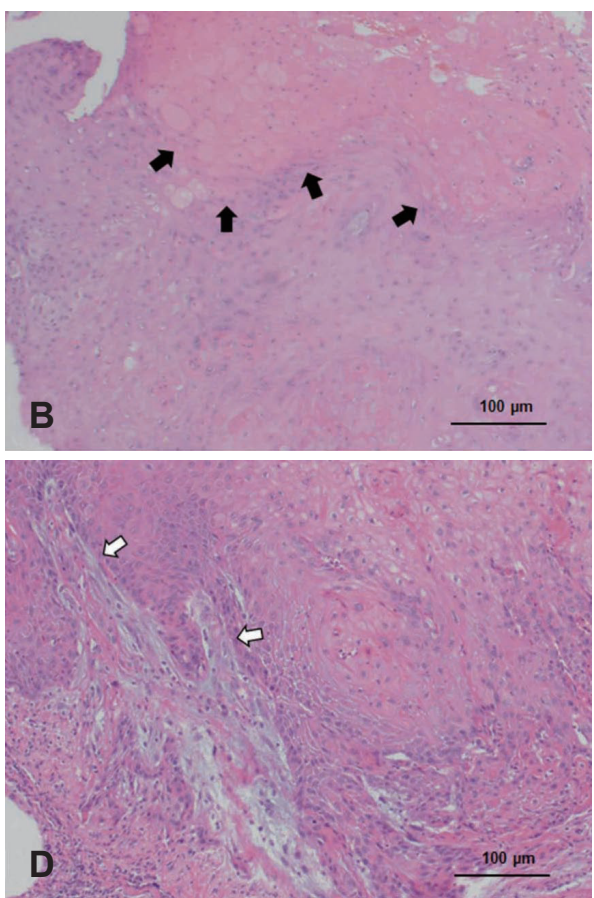

Fig. 2. Histopathologic findings. Thicken keratin layer (asterisk) and acanthotic epithelium (black arrowhead) were noted in the epithelial layer of the specimen obtained from incisional biopsy (H\&E stain) (A). Definite stromal invasion was not observed in the high magnification (black arrows) (H\&E stain) (B). However, in the completely excised specimen, atypical squamous cells and the early stage of a stromal invasion were noted (white arrowhead and white arrows) (H\&E stain) (C and D). 
포암의 침윤 정도와 전이여부를 알기 위하여 경부 자기공명영 상촬영과 양전자 컴퓨터단층촬영(positron emission tomography-CT)을 시행하였고, 뚜렷하게 관찰되는 편평세포암의 잔류와 타 장기로의 전이는 관찰되지 않았다. 상기 소견들을 종합적으로 고려하여 Pittsburgh tumor staging system 기준 에 따라 최종적으로 T1NOM0로 진단하였으며, 임상병기, 일 차수술에서 얻은 조직소견, 이전 방사선 치료로 인한 수술 후 합병증 발생 가능성 등 다양한 요인을 고려하여 변연절제술 (sleeve resection)을 계획하였다.

수술은 전신마취하에 시행되었으며, 외이도 절개를 통해 수술 부위를 노출시켰다. 수술 소견상 수술상처에 육아조직 이 자라나 있었고, 그 주위로 경한 발적과 부종소견이 관찰되 었다. 그러나 잔여 종물은 관찰되지 않았다. 수술은 상처 부 위에 형성된 육아조직을 포함하여 주위 정상 피부와 기저부 연골조직을 모두 제거하였으며, 수술 중 동결절편조직검사를 통해 모든 절제면에 편평세포암 음성을 확인하였고, 피부동 종이식을 통해 결손부위를 보완해주고 수술을 종료하였다. 현재 수술 후 4개월째 경과관찰 중으로 좌측 외이도에 편평 상피세포암의 재발 소견은 관찰되지 않으며, 수술부위와 피 부동종이식 부위는 잘 회복되었고, 추가적인 방사선 치료 없 이 정기적인 외래 경과관찰을 계획 중에 있다.

\section{고 찰}

외이도에서 발생하는 악성종양 중 편평세포암이 가장 흔하 며, 대부분 원발암이고 전이암은 극히 드물다. ${ }^{1)}$ 외이도 편평 세포암은 중이나 측두골 내의 내경동맥, 안면신경관, 와우각, 전정기관, 이하선, 경부 림프절 등으로 빠르게 침윤 또는 전 이되므로 초기의 빠른 진단이 중요하다. ${ }^{7)}$ 하지만 외이도 신 체검사 소견만으로는 외이도 편평세포암은 만성 외이도염, 용 종, 광선각화증, 보웬병, 육아종, 각화극세포종 등의 양성종양 및 질환과의 감별이 어려울 경우가 많아 조직학적 생검을 통 한 감별이 반드시 필요하여 진단이 늦어지는 경우가 많다. 37,8)

분화가 좋은 편평상피세포암은 양성종양인 각화극세포종 과 임상 및 병리학적으로 유사한 소견을 보이는데, 특히 편평 상피세포암이 각화극세포종의 양상을 보이는 경우에는 감별 이 매우 어렵다. ${ }^{3,7}$ 각화극세포종은 피부의 양성종양으로 중 년이나 노인층에서 태양광선에 노출되는 부위에 주로 단발성 으로 발생하고, 조직병리학적 소견은 분화구 모양의 반구형 태를 가지며 주변 상피의 증식이 현저하며 비정형의 종양 세 포 침윤이 없는 구조를 보이는데, 특징적으로 각질형성세포와 각질전의 축적이 관찰된다. ${ }^{3,9)}$ 반면에 분화가 좋은 편평상피 세포암의 경우에는 분화구 모양의 구조는 가지고 있지 않으
며 개별 세포의 각화 현상이 관찰되고, 현저한 세포의 이형 성을 특징으로 한다. ${ }^{37,8)}$ 이러한 두 종양의 조직병리학적 감별 에서 가장 중요한 것은 종양 조직의 전체적인 모양과 세포들 의 이형성 발생여부로 절개생검으로는 감별이 불확실하고 종 양의 변연과 기저부를 충분히 포함하는 절제생검이 반드시 필요하다.

현재까지 밝혀진 외이도 편평상피세포암의 발생원인은 과 도한 자외선 노출, 진주종, 만성 외이도염 등이 있으며, 드물 지만 방사선 치료도 중요한 원인 중 하나로 알려져 있다.-6) 방 사선 치료는 많은 두경부 악성종양에서 중요한 치료 중 하나 로 측두골 및 이와 연관된 구조물들은 두경부 종양의 방사 선 치료시에 주로 포함되는 부위인데, 이로 인해 방사선 치료 후 합병증으로 청력저하와 골괴사, 유스타키오관의 기능저 하, 방사선 연관 악성종양 등이 발생한다. ${ }^{5,10)}$ 방사선 치료 후 발생한 악성종양으로 진단하기 위해서는 이전에 방사선 치료 를 시행한 병력이 있고, 발생한 부위가 이전에 시행한 방사선 치료 범위 내에 포함되어야 하고, 발생 시기가 방사선 치료를 종결한 후 2년 이내이며, 원발암과 조직병리학적으로 차이가 있어야 한다. ${ }^{5,6,11)}$ 본 증례의 좌측 외이도 편평상피세포암의 경우에도 기무라씨병으로 인해 좌측 이하선 및 이하선 상방 부에 방사선 치료를 받은 병력과 방사선 치료 후 2년 이내 발 생한 점 등을 고려하여 방사선 치료가 외이도 편평상피세포 암의 발생원인이 되었다고 생각된다.

방사선 치료 후 발생한 외이도 편평상피세포암은 발생빈도 가 굉장히 적고 증례수가 많지 않아 치료방법에 대해 명확히 확립이 되어 있지 않지만, 편평세포암 음성 절제면이 확보되 는 근치적 적출술이 환자의 예후와 생존율에 중요한 영향을 미친다. ${ }^{1,2,7)}$ 그러나 무엇보다도 가장 중요한 것은 병기가 더 진 행하기 전인 초기에 빠른 진단을 내리는 것이다. 그러므로 두 경부에 방사선 치료를 받은 병력이 있는 환자에서 이루와 이 통, 이충만감 등의 증상을 호소할 경우에는 외이와 중이에 대한 보다 세심한 신체검사가 필요하고, 병변에 대한 적극적 인 영상학적 검사와 조직병리학적 검사가 시행되어야 한다.

\section{REFERENCES}

1) Jung SH, Kim CW, Kim HS, Lee WS. Squamous cell carcinoma of the external auditory canal: treatment results of 15 cases. Korean J Otolaryngol-Head Neck Surg 2005;48(2):136-41.

2) Park KT, Song JJ, Jang JH, Oh SH, Kim CS, Chang SO, et al. The analysis of prognostic factor and treatment outcome of malignancies of the external auditory canal. Korean J Otorhinolaryngol-Head Neck Surg 2010;53(5):275-83.

3) Kim CW, Kim CH, Lim YH, Nam ES. A case of keratoacanthomalike squamous cell carcinoma of the auricle. Korean J OtolaryngolHead Neck Surg 2006;49(2):225-7.

4) Kuhel WI, Hume CR, Selesnick SH. Cancer of the external auditory canal and temporal bone. Otolaryngol Clin North Am 1996;29(5): 
$827-52$

5) Wang J, Xie B, Dai C. Clinical chracteristics and management of external auditory canal squamous cell carcinoma in post-irradiated nasopharyngeal carcinoma patients. Otol Neurotol 2015;36(6):1081-8.

6) Shu MT, Lin HC, Lee JC, Chen BF. Radiation-induced squamous cell carcinoma of the external auditory canal. Otol Neurotol 2011;32(3): e24-5.

7) Ouaz K, Robier A, Lescanne E, Bobillier C, Morinière S, Bakhos D. Cancer of the external auditory canal. Eur Ann Otorhinolaryngol Head Neck Dis 2013;130(4):175-82.

8) Majores M, Bierhoff E. [Actinic keratosis, Bowen's disease, keratoacanthoma and squamous cell carcinoma of the skin]. Pathologe
2015;36(1):16-29.

9) Chon HJ, Son SJ, Kim DJ. p53 protein and Ki-67 antigen expression in keratoacanthoma and keratoacanthoma-like squamous cell carcinoma. Korean J Dermatol 2000;38(7):874-9.

10) Lambert EM, Garden AS, DeMonte F, Roberts DB, Gidley PW. Radiation-associated malignancies of the ear canal and temporal bone. Laryngoscope 2015;125(5):1198-204.

11) Tay G, Tan HK, Thiagarajan A, Soo KC, Iyer NG. Squamous cell carcinoma of the ear arising in patients after radiotherapy for nasopharyngeal carcinoma. Eur Arch Otorhinolaryngol 2014;271 (1):149-56. 